\title{
POTENSI KULIT KOPI DAN KULIT KETELA SEBAGAI ADITIF PADA PEMBUATAN SILASE RUMPUT GAJAH (Pennisetum purpureum) \\ (Potential of Coffe and Cassava Peel as Additive For Making An Elephant Grass \\ (Pennisetum purpureum) Silage)
}

\author{
Joko Daryatmo ${ }^{1}$, Zainal Arifin ${ }^{1}$ dan Dominggus L. Ledoh ${ }^{2}$ \\ ${ }^{1)}$ Sekolah Tinggi Penyuluhan Pertanian Magelang \\ Jl. Magelang-Kopeng Km 7 Purwosari Tegalrejo Magelang 56192 \\ e-mail: jkodr@yahoo.com \\ ${ }^{2)}$ Balai Penyuluhan Pertanian Rote Barat Laut \\ Rote, Rote Ndao, Nusa Tenggara Timur
}

\begin{abstract}
The study was conducted to determine the effect of the use of coffe and cassava peel to the organoleptic of elephant grass silage. The study was conducted using a completely randomized design (CRD) consisting of 3 treatment are: PO (Elephant grass (Pennisetum purpureum) 100\%) as a control, P1 (elephant grass+coffe peel), P2 (elephant grass +cassava peel, with 3 replications. The variables measured were: color, odor, $p H$, texture and physical condition. The results showed that treatment P2 (elephant grass+cassava peel) is the best composition to produce silage based on the observation of the organoleptic and physical conditions of the silage.
\end{abstract}

Keywords: Coffe peel, Cassava peel, Silage, Pennisetum purpureum

\begin{abstract}
ABSTRAK
Penelitian dilakukan untuk mengetahui pengaruh penggunaan kulit kopi dan kulit ketela terhadap organoleptik silase rumput Gajah. Penelitian dilakukan dengan menggunakan Rancangan pengkajian mengunakan Rancangan Acak Lengkap (RAL) dengan 3 perlakuan dan 3 ulangan yaitu rumput gajah (Pennisetum purpureum) sebagai kontrol (P0),rumput gajah tambah kulit kopi sebagai (P1) dan rumput gajah tambah kulit singkong sebagai (P2). Simpulan yang diperoleh dari hasil kajian bahwa perlakuan P1 dan P2 hasilnya sama baiknya, dibuktikan dengan uji organoleptik dan kondisi fisik silase.
\end{abstract}

Kata Kunci : Kulit kopi, Kulit Ketela, Silase, Pennisetum Purpureum

\section{PENDAHULUAN}

Pembangunan Peternakan merupakan bagian dari pembangunan pertanian, dari tahun ketahun terus berkembang dan mampu memberikan sumbangan yang cukup dalam pembangunan nasional dan sampai saat ini pemerintah masih menitikberatkan pembangunan nasional pada sektor peternakan. Arah pembangunan peternakan adalah meningkatkan gizi masyarakat dan kualitas produksi ternak menuju swasembada daging. Salah satu faktor yang perlu dan penting dalam usaha untuk mencapai keberhasilan pembangunan 
dibidang peternakan adalah penyediaan pakan yang cukup dan berkualitas karena hijauan makanan ternak merupakan pakan utama bagi ternak ruminansia, guna meningkatkan produksi.

Produksi hijauan pakan menjadi lebih terbatas karena pertambahan penduduk yang membutuhkan lahan untuk pemukiman, perluasan lahan untuk produksi pangan dan pembangunan subsektor lainnya. Oleh sebab itu penyediaan pakan memerlukan teknologi pengolahan hijauan yang relatif sederhana untuk mendukung ketersediaan pakan sepanjang tahun.

Ketersediaan pakan sepanjang tahun merupakan persyaratan mutlak bagi kelangsungan usaha peternakan. Biaya untuk menyediakan pakan ini menempati porsi terbesar dalam biaya produksi, Besarnya biaya tersebut ditentukan oleh jenis dan bangsa ternak yang dikembangkan. Biaya pakan yang semakin mahal perlu disiasati dengan memanfaatkan bahan pakan alternatif yang murah antara lain kulit kopi dan kulit ketela atau menyediakan alat dan mesin untuk meramu pakan sehingga harga pakan lebih murah.

Pengadaan pakan ruminansia pada musim kemarau tampaknya masih menjadi masalah yang serius. Upaya mempertahankan populasi ternak yang ada harus diiringi dengan penyediaan pakan ternak yang cukup maupun kualitas yang tersedia sepanjang waktu dan sepanjang musim untuk menjaga agar produktivitas ternak tidak menurun. Sebagian petani peternak belum memanfaatkan hijauan dengan sempurna terutama hijauan rumput untuk dijadikan sebagai pakan yang bernilai gizi baik untuk ternak sapi, terutama di musim kemarau karena kesulitan untuk mengawetkan rumput sebagai persediaan pakan. Hal ini dipengaruhi oleh keterbatasan pengetahuan, sikap dan keterampilan yang dimiliki oleh petani ternak. Petani ternak masih ada yang belum mengetahui tentang teknologi silase sebagai salah satu teknologi konservasi hijauan dan manfaatnya untuk mengawetkan hijauan pakan untuk digunakan di musim kemarau.

\section{MATERI DAN METODE}

Lokasi pengkajian pembuatan silase rumput gajah dilaksanakan di Lab. Pengolahan Pakan dan Kebun Rumput STPP Magelang

\section{Materi}

Alat yang digunakan dalam pelaksanaan penelitian ini adalah: a) Timbangan duduk kapasitas $15 \mathrm{~kg}$, b) Alat pemotong rumput makanan ternak (chopper), c) Silo (kantong plastik) 0,8 mm 1 rol, d) Tali plastik, e) karung kapasitas 50 kg 9 buah, f) 1 rol plastik kurung (90x20 $\mathrm{cm})$, g) Terpal ukuran $4 \times 5 \mathrm{~m}, \mathrm{~h}$ ) Handphone kamera 1 buah, i) $\mathrm{pH}$ indicator. Bahan yang dipakai untuk pelaksanaan dalam pengkajian adalah : a) Rumput gajah $90 \mathrm{~kg}$, b) kulit kopi $45 \mathrm{~kg} \mathrm{c)}$ dan d) Kulit singkong $45 \mathrm{~kg}$.

\section{Metode}

Penelitian menggunakan rancangan acak lengkap (RAL) dengan 3 perlakuan dan 3 ulangan. Perlakuan penelitian terdiri dari: $\mathrm{P} 0=$ Rumput Gajah tanpa penambahan aditif (kontrol); P1= Rumput Gajah+kulit kopi; P2= Rumput Gajah+kulit ketela. Setelah menjadi silase, selanjutnya dilakukan pengamatan meliputi: a) Pengamatan organoleptik (warna, bau, tekstur dan $\mathrm{pH}$ ), dan b) Kondisi fisik silase. Data yang didapatkan lalu dianalisis statistik, dilanjutkan dengan uji Beda Nyata Terkecil (Steel dan Torrie, 1994). 
HASIL DAN PEMBAHASAN

Pengamatan Organoleptik

Pengamatan organoleptik silase rumput gajah meliputi: warna, bau, tekstur dan $\mathrm{pH}$ yang terlihat dari silase itu sendiri. Penilaian dimasukkan dalam blangko analisa fisik silase rumput gajah. Setelah diberi penilaian, kemudian hasil tersebut direkap dan hasil rekapitulasi karakter fisik rumput gajah dapat dilihat pada tabel di bawah ini.

\section{Tekstur silase}

Hasil penilaian tekstur silase pada 3 perlakuan dapat dilihat pada Tabel 1 dibawah ini

Tabel 1. Rata-rata karakter fisik tekstur silase rumput gajah dengan berbagai perlakuan

\begin{tabular}{|c|c|c|}
\hline \multicolumn{3}{|c|}{ Tekstur silase } \\
\hline Perlakuan & Rata-rata skor & Keterangan \\
\hline P0 (kontrol/rumput gajah 100\% & $4,33^{\mathrm{a}}$ & tekstur basah/sedikit berair dan menggumpal \\
\hline P1 (rumput gajah+Kulit kopi) & $4,33^{\mathrm{a}}$ & tekstur basah/sedikit berair dan menggumpal \\
\hline P2 (rumput gajah+Kulit ketela) & $5,00^{\mathrm{b}}$ & lunak, lembut/kering dan tidak menggumpal \\
\hline
\end{tabular}

Dari hasil analisis statistik dapat P2, tekstur silase lunak, lembut dan tidak dilihat bahwa P0 dan P1 hasilnya tidak menggumpal. Hali ini sesuai pendapat berbeda nyata atau sama dan lebih jelek Siregar (1996) dalam Prabowo et al. dibanding perlakuan P2 (P0 dan P1 (2013), secara umum silase yang baik memiliki tekstur basah, sedikit berair dan mempunyai ciri-ciri, yaitu tekstur masih menggumpal). Sedangkan pada perlakuan jelas, tidak menggumpal, seperti alamnya.

\section{Warna silase}

Hasil penilaian warna silase pada 3 perlakuan tertuang dalam Tabel 2 dibawah ini

\begin{tabular}{lll}
\hline \multicolumn{1}{c}{ Perlakuan } & $\begin{array}{l}\text { Warna silase } \\
\text { Rata-rata skor }\end{array}$ & \multicolumn{1}{c}{ Keterangan } \\
\hline P0 (kontrol/rumput gajah 100\% & $4,33^{\text {ns }}$ & Mendekati hijau kekuningan \\
P1 (rumput gajah + Kulit kopi) & $5,00^{\text {ns }}$ & Hijau kekuningan \\
P2 (rumput gajah + Kulit ketela) & $5,00^{\text {ns }}$ & Hijau kekuningan \\
\hline
\end{tabular}

Tabel 2. Rata-rata karakter fisik warna silase rumput gajah dengan berbagai perlakuan.

${ }^{\mathrm{ns}}$ non signifikan $(\mathrm{P}>0,05)$

Dari hasil analisis statistik dapat dilihat bahwa warna silase yang dihasilkan dari perlakuan kontrol yaitu mendekati warna hijau kekuningan tidak nyata dibandingkan dengan P1 dan P2 sehingga warna ketiga perlakuan dapat dianggap sama, hal ini sesuai ciri silase yang baik yaitu hijau kekuningan (Yusriani, 2015).

\section{Bau silase}

Hasil penilaian warna silase pada 3 perlakuan tertuang dalam Tabel 3 dibawah ini. 


\begin{tabular}{cll}
\hline \hline & \multicolumn{2}{c}{ Bau silase } \\
Perlakuan & Rata-rata skor & \multicolumn{1}{c}{ Keterangan } \\
\hline P0 (kontrol/rumput gajah 100\%) & $4,00^{\mathrm{a}}$ & Berbau rumput \\
P1 (rumput gajah + Kulit kopi) & $5,00^{\mathrm{b}}$ & Berbau harum, manis dan asam \\
P2 (rumput gajah + Kulit ketela) & $4,67^{\text {ab }}$ & Mendekati berbau harum, manis dan asam \\
\hline Tabel 3. Rata-rata karakter fisik bau silase rumput gajah dengan berbagai perlakuan. \\
a,b Superskrip yang berbeda pada & kolom yang & sama menunjukkan perbedaan yang \\
signifikan $(\mathrm{P}<0,05)$ & &
\end{tabular}

Dari hasil analisis statistik diketahui bau silase antar perlakuan yang berbeda menunjukkan perbedaan yang nyata, antar perlakuan P0, P1, dan P2. Bau yang dihasilkan dari perlakuan P0 adalah bau rumput, jika dibandingkan dengan perlakuan P1 dan P2 bau yang dihasilkan adalah berbau harum, manis dan asam, sedangkan P0 nyata berbeda $(\mathrm{P}<0,05)$ memiliki bau yang jauh dari ciri bau silase yang baik karena berbau busuk atau bau rumput, sedangkan yang dihasilkan P1 dan P2 adalah berbau wangi, agak asam. Bau asam yang dihasilkan oleh silase disebabkan karena dalam proses pembuatan silase bakteri anaerob aktif bekerja dalam hal ini menghasilkan asam organik oleh karena itu asam dapat terbentuk. Wallace dan Chesson (1995) dalam Kojo et al. (2015) menyatakan bahwa asam yang dihasilkan selama ensilase adalah asam laktat, propionate, formiat, suksinat, dan butirat. Dengan demikian, bau asam dapat dijadikan sebagai indikator untuk melihat keberhasilan proses ensilase, sebab untuk keberhasilan proses ensilase harus dalam suasana asam.

\section{4. $\mathbf{p H}$ silase}

Hasil penilaian pH silase pada 3 perlakuan tertuang dalam Tabel 4 dibawah ini

Tabel 4. Rata-rata karakter fisik pH silase rumput gajah dengan berbagai perlakuan.

\begin{tabular}{|c|c|c|}
\hline & pH silas & \\
\hline Perlakuan & Rata-rata skor & Keterangan \\
\hline P0 (kontrol/rumput gajah $100 \%$ & $2,33^{\mathrm{a}}$ & Sedikit mendekati pH 4,5 (pH 5) \\
\hline P1 (rumput gajah + Kulit kopi) & $3,67^{\mathrm{b}}$ & Mendekati pH 4,5 (pH 4) \\
\hline P2 (rumput gajah + Kulit ketela) & $3,67^{\mathrm{b}}$ & Mendekati pH 4,5 (pH 4) \\
\hline
\end{tabular}

Dari hasil analisis statistik diketahui $\mathrm{pH}$ silase antara perlakuan $\mathrm{P0}$ dibandingkan dengan P1 dan P2 menunjukkan perbedaan yang nyata, sedangkan antara perlakuan P1 dan P2 tidak menunjukkan perbedaan nyata. $\mathrm{pH}$ yang dihasilkan perlakuan $\mathrm{P} 0$ yaitu 5 sedangkan $\mathrm{pH}$ yang dihasilkan perlakuan P1 dan P2 yaitu 4. Dilihat dari data tersebut sesuai dengan pendapat Perry et al. (2003) dalam Jasin (2014) yang menyatakan bahwa penambahan bahan kaya akan karbohidrat dapat mempercepat penurunan $\mathrm{pH}$ silase karena karbohidrat merupakan energi bagi bakteri pembentuk asam laktat.

\section{Kondisi fisik silase}

Dari hasil analisis statistik diketahui kondisi fisik silase antara perlakuan P0 dengan P1 dan P2 menunjukkan perbedaan 
yang nyata $(\mathrm{P}<0,05)$, dengan hanya perlakuan P1 yang yang kondisi fisiknya bebas jamur. Dimungkinkan kurang padatnya silo pada perlakuan P0 dan P2 sehingga jamur masih dapat tumbuh. Stoskops (1981) menyatakan bahwa jamur akan tumbuh pada keadaan aerob yang menyebabkan silase menjadi apek dan berjamur. Selanjutnya Woolford (1984), menyatakan bahwa Filamentous fungi tidak banyak mempengaruhi proses ensilase tetapi dapat menyebabkan banyaknya silase yang terbuang terutama pada permukaan akibat adanya kemasukan udara. Jamur biasanya tumbuh pada bagian atas atau bagian sisi dari silo dan jumlahnya sangat tergantung pada padat atau tidaknya bahan di dalam silo (Mc. Collough, 1978).

Hasil penilaian kondisi fisik silase pada 3 perlakuan tertuang dalam Tabel 5 dibawah ini

Tabel 5. Rata-rata skor kondisi fisk silase rumput gajah dengan berbagai perlakuan.

\begin{tabular}{|c|c|c|}
\hline \multicolumn{3}{|c|}{ Kondisi fisik silase } \\
\hline Perlakuan & Rata-rata skor & Ket \\
\hline P0 (kontrol/rumput gajah $100 \%$ & $3,67^{\mathrm{a}}$ & Sedikit berjamur \\
\hline P1 (rumput gajah + Kulit kopi) & $5,00^{\mathrm{b}}$ & Bebas jamur \\
\hline P2 (rumput gajah + Kulit ketela) & $4,33^{\mathrm{b}}$ & Sedikit sekali berjamur \\
\hline
\end{tabular}

\section{SIMPULAN DAN SARAN Simpulan}

1. Tekstur silase dengan perlakuan P0 dan P1 menunjukan hasil yang sama atau tidak nyata yaitu tekstur yang basah atau sedikit berair dan menggumpal sedangkan untuk perlakuan P2 berbeda nyata dengan perlakuan P0 dan perlakuan P1 yaitu tekstur lunak basah atau sedikit berair dan tidak menggumpal.

2. Warna silase dengan perlakuan P0, P1 dan P2 tidak berbeda nyata atau non signifikan sehingga menunjukan hasil dari warna silase mendekati hijau kekuningan

3. Bau silase dengan perlakuan P0 menunjukan hasil yang berbeda nyata dengan perlakuan P1 dan P2 yaitu bau untuk P0 berbau harum, manis dan asam sedangkan untuk P1 dan P2 bau manis agak ke asam.

4. Rasa silase dengan perlakuan P0 dan P1 menunjukan hasil yang berbeda nyata dengan perlakuan P2 berbeda rasa yaitu untuk perlakuan $\mathrm{P} 2$ rasa asam seperti karamel

5. $\mathrm{pH}$ silase dengan perlakuan $\mathrm{P} 0$ menunjukan hasil yang berbeda nyata dengan perlakuan $\mathrm{P} 1$ dan $\mathrm{P} 2, \mathrm{pH}$ yaitu untuk P0 (5) sedangkan untuk P1 dan P2 (4).

6. Kondisi fisik silase dengan perlakuan P0 menunjukan perbedaan yang nyata dengan perlakuan P1 dan P2 berbeda kondisi fisik yaitu untuk P0 sedikit berjamur sedangkan untuk P1 dan P2 bebas jamur.

\section{Saran}

Dalam pembuatan silase perlu diperhatikan prinsip-prinsip pembuatan supaya menghasilkan silase yang baik karena silase yang baik bisa diberikan pada ternak khususnya ternak ruminansia. 


\section{DAFTAR PUSTAKA}

Jasin, Ismail. 2014. Pengaruh Penambahan Molases dan Isolat Bakteri Asam Laktat dari Cairan Rumen Sapi PO Terhadap Kualitas Silase Rumput Gajah (Pennisetum purpureum). Agripet Vol 14, No. 1, April 2014. P 50-55

Kojo M, Raldi, Rustandi, Y. R. L. Tulung, dan S.S.Malalantang. 2015. Pengaruh Penambahan Dedak Padi Dan Tepung Jagung Terhadap Kualitas Fisik Silase Rumput Gajah.

http://download.portalgaruda.org/a rticle.php? article $=291945 \&$ val $=10$ 04\&title=pengaruh $\% 20$ penambaha n\%20dedak\%20padi\%20dan\%20te pung $\% 20$ jagung $\% 20$ terhadap $\% 20 \mathrm{k}$ ualitas\%20fisik\%20silase\%20rum put $\% 20$ gajah $\% 20 \% 28$ pennisetum \%20purpureumcv.hawaii\%29.

Diakses Tanggal 30 Maret 2016.

Mc. Collough, M. E. 1978. Silage Some General Consediration Fermentation Silage A Review. Ed. By Mc Collough National Feed Ingredients Association. Iowa.

Prabowo, A., A. E. Susanti, dan J. Karman. 2013. Pengaruh penambahan bakteri asam laktat terhadap $\mathrm{pH}$ dan penampilan fisik silase jerami kacang tanah. Seminar Nasional Teknologi dan Veteriner.

Steel, R. G. D and J. H. Torrie. 1994. Prinsip dan Prosedur Statistik. Terjemahan: B. Sumantri. PT Gramedia Pustaka Utama. Jakarta.

Stoskops, N. C. 1981. Understanding Crop Production. Reston Publishing Company, Inc. Reston. Virginia.
Subekti, Ganjar, Suwarno dan Nur Hidayat. 2013. Penggunaan Beberapa Aditif dan Bakteri Asam Laktat Terhadap Karakteristik Fisik Silase Rumput Gajah Pada Hari Ke-14. http://jos.unsoed.ac.id/index.php/ji p/article/viewFile/665/329.

Diakses Tanggal 20 Februari 2016.

Woolfrod, M. K. 1984. The Silage Fermentation. Marcel Dekker, Inc. New York

Yusriani, Yenni. 2015. Pengawetan Hijauan dengan Cara Silase Untuk Pakan Ternak Ruminansia. http://nad.litbang.pertanian.go.id/ind /index.php/info-teknologi/714pengawetan-hijauan-dengan-carasilase-untuk-pakan-ternakruminansia. Diakses Tanggal 12 Januari 2017. 